\title{
LED 照明製品の開発と地域の連携
}

\section{ABSTRACT}

In Tottori, I established a company which performs development, production and sale of LED lighting equipment. The company utilizes local resources of Tottori and is expanding its business.

Why did I choose Tottori as the location for my company? I will introduce Tottori and the advantages of doing business there.

\section{1，鳥取での LED 照明製品開発}

なぜこの事業を鳥取で起業したのか，自己紹介を通し て説明したい。私は電機メーカーの半導体プロセスエン ジニアとして，20年以上過ごしてきた．半導体チップを 作るのが本業で, メモリ，マイコンの大量生産に従事し た。 その後，半導体レーザーなどの生産に従事し，ここ で, LED とのご縁ができた. LED 光源の開発のため, 子会社の照明器具製造会社に出向し, ここで照明器具の なんたるかを勉強した，半導体製品であるLED と，電 気用品である照明製品という相互に異なる技術的特徵と 市場の慣習を持つ製品の両方を勉強する幸運に恵まれた のである。この経験をもとに，2年半ほど前にスピンア ウトし，LED 照明器具の開発を本業とした．当初の半年 は, 群馬の会社で, LED 光源とそれを使った照明器具 の開発を行った. LED 光源の性能・コストの実現にめぞ がたち，いよいよ量産開始というところで，岡山の水道 会社の子会社として，その隣県である鳥取で起業した。

鳥取を選んだのは，地縁・血縁からいうと，家内の実 家があり，私の出身校もありということになる，がしか し，これは後付けの理由である. 本当の理由は，日本の どこよりも LED 照明器具の開発がしやすいと判断した からである．前々職のとき，投資を極力抑え，LED照 明器具を光源から開発・製造する夢を持っていた，日本 各地を調べたところ，LEDの組み立て技術，LED の信 頼性評価技術，電子部品の製造技術，板金などの加工技 術がそろっていたのは鳥取市近郊だけであった。ここに は鳥取三洋電機という会社があり，高級自動車向けの LED ストップランプの製造が行われ，一方では，電気 炊飯器の製造も行っていた。 また, 行政は電子産業を, そのなかでも LED 産業をのばしていこうと，光束測定 機, 配光測定機, LED の信頼性評価設備を整備し, わ れわれのような経営基盤の弱いベンチャーにも開放して
いた，そして，この鳥取市には，それらの技術を担って こられた技術者の方々が，多数お住まいになっていた．

評価設備・加工技術とその設備，技術者が狭い地域で そろっている場所は鳥取市をおいて，ほかにはみつけき れなかった。そして，2010年 2 月，岡山の会社の子会社 として起業した。

\section{2、鳥取で始めてよかったこと, 悪かったこと}

\section{1 地域の支援}

当初の狙いと扮り，鳥取県が保有する設備による評価 は強力な武器となった。 LED チップ・メーカー, 蛍光 体や封止材などの材料メーカー, LED 電球などのメー カーとの議論に限らず，お客様への提出デー夕の作成に 大いに活用した。自社技術の位置づけが明確になり，さ らなる向上のため何をし，何をしないのかという経営判 断が設備投資を抑制しつつも的確にできている.

\section{2 課題}

照明設計の相談をできる方が，県内にほとんでいない ことが課題である，現在は，県外の照明設計をされてい る方にお願いをしている。

事業を育てていただくという観点からは，悪いところ はなく，このところで，各方面からのご支援・ご鞭撻を いただき，なんとか，当初の死の谷を通り過ごせたかな と思っている。具体的には，県・市からの補助金という ご支援が非常に助かった。また, 経営という未知の分野 に足をいれているわけであるが，わからないところやや りくりの仕方なぞを県・市・金融機関の方々に教えてい ただきここまでたどり着くことができた。

\section{2 年たっての現状}

現在弊社は, 開発工程のみの会社として運営している. 私を入れて，7名で業務を進めている. 光源開発, 電源 開発，灯具設計，組み立て材料評価，信頼性評価が，社 
内の業務であり，これらすべてにベテランのエンジニア を配置している (1 人複数業務). 照明設計については, 社外にお願いをしている，照明器具を構成する各要素に ついて責任の持てる体制，蛍光灯などの照明器具と同等 の信頼性を確保できる体制をと考えてやってきた。この ような形態の事業運営であっても, 現在まで弊社起因の 故障は発生していない.

製造は，地元企業を中心にすべて外注による加工であ る。県内には，照明器具全体の加工をしている会社はな いので，各社に依頼できる仕様に設計・分解をし，その アレンジを弊社が行うことで，狙ったとおりのものが生 産できている，弊社は，工場部門は持っていない。しか し，言い換えれば，弊社の方法で，鳥取で事業をすれば， その必要がないのである。今後は，この形をさらに磨き 上げ，より効率的に，より短納期で生産できるよう工夫 を重ねていきたいと考えている。

また，ベテランしかいない現状では，将来の展開が難 しくなると考えている。これを，いかに若い人にバトン タッチし, 発展させていくかが, 大きな課題である。

このように, 地域資源を最大限に生かす形で起業をし， やっと 3 期目にはいることができた。また，これから大 きく伸長すると予測されている LED 照明製品において， 光源の製造，電源の製造，灯具の製造，品質保証を一気 通貫でできるメーカーは，全国的に非常に数が少ないが， 鳥取の特徴はここにある。それぞれの企業は中小零細で はあるが，相互に連携することが可能であり，地域とし てみれば，LED照明製品を製造するに最適である。

技術的背景は，COB（Chip on Board）技術をもとに， LED 光源の開発とそれを使った LED 照明器具の開発を 行っている。一般的な SMD（Surface Mount Device）と呼 ばれる LEDの構造とわれわれが行っている COB の構造 の比較を図 1 に示す。

COB の方が構造が単純で，放熱に優れていることが わかる、弊社は，この光源をもとに，LED照明器具を 開発し, より高効率, より低価格な照明器具の提供を目 指している.

これまでに，弊社で開発・製造し納入させていただい た事例を紹介する。図2に弊社が製造している COBを 使った平面光源の例を示す。図 3 は，この光源の点灯例 である。これをもとに客先のニーズに合った照明器具の 開発をこころがけている.

図4は，鳥取市における施行例である。床面照度は， 従来の蛍光灯器具と同一でありながら, 消費電力は, 30\%以上削減できている。図5は，このLEDモジュー ルをRGB 化し，演出照明として使ったものである，ネ オン管のように大光束で, さらに色変化ができる照明器 具とした，消費電力的には，おおむね半減ができている。 弊社は，光源から製造しているので，お客様のニーズ

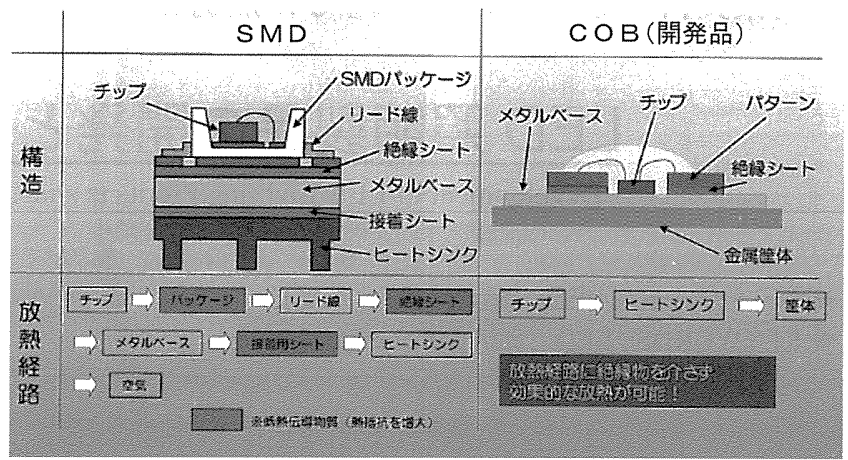

図 1 LED モジュールの構造と放熱経路の比較例

Fig.1 Comparative example of the structure and heat control on the LED module.

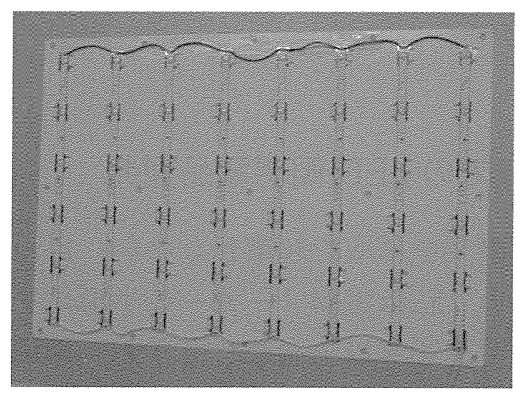

図 2 LED 光源の事例

Fig.2 Example of LED light source.

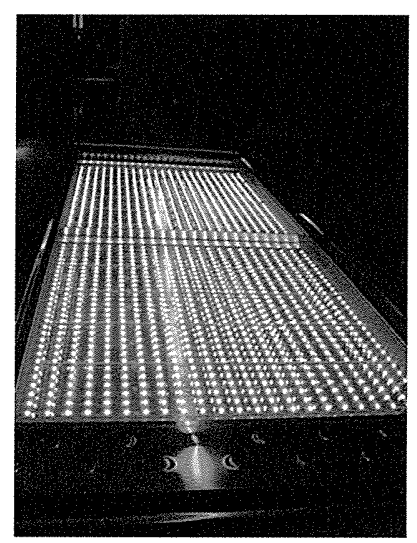

図 3 LED 光源点灯例

Fig.3 Case of LED lighting.

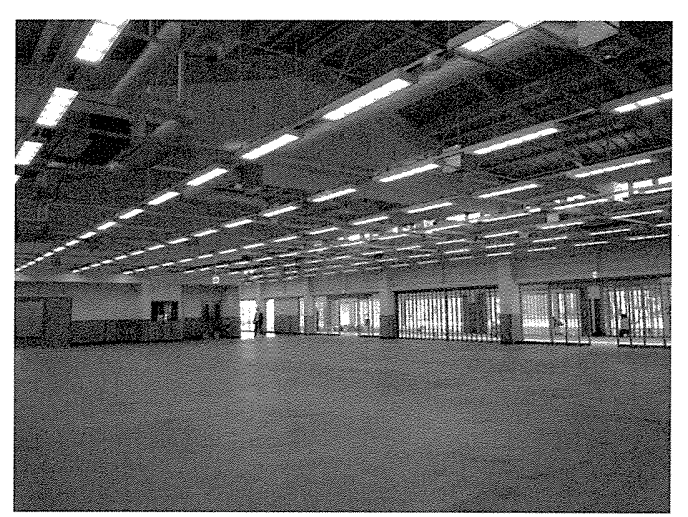

図4 LED 照明器具設置例

Fig.4 Example of installation of LED lighting fixtures. 
に合ったチップ選定と組み合わせが可能となる。また， 電源回路の技術者もいるので, 駆動回路のカスタマイズ も可能である，道路灯については，日本街路灯製造様と 共同で，以下のような灯具も開発した。倉敷駅北口に設 置されている。 $1 \mathrm{~kW}$ の水銀灯灯具を $120 \mathrm{~W}$ 程度の LED 道路灯で置き換えができた（路面照度は，道路照明の基

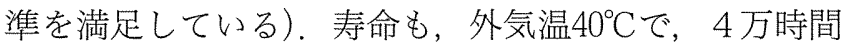
以上の推定值となっている（倉敷市の平均気温は, $\left.15.2^{\circ} \mathrm{C}\right)$.

また，既存の水銀灯灯具を LED 化したいという要望 があったので，図6および図 7 に示すような屋外用照明 器具も製作した。

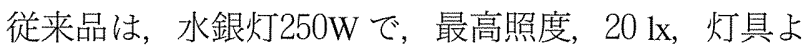
り $10 \mathrm{~m}$ 離れた路面で $5 \mathrm{~lx}$ である，弊社のものは，消費 電力72W，最高照度 $38 \mathrm{~lx} ， 10 \mathrm{~m}$ 離れた路面照度は $5 \mathrm{~lx}$ で ある、これらのほとんどは，鳥取で見ることが可能であ る。少し変わったところでは，図8のような，白色と RGB を使った検品用コンベアに光源と駆動回路を開発 した．色の異なったゼリーなどの検品に効果を発揮して いる，また，従来のコンベアで使用していた蛍光灯のよ うなフリッカがないので, 疲労しにくくなったと作業者 から聞いている。

\section{4. 今後の展開}

以上ご紹介した形態の事業運営においては，光源技術 がLED 照明製品開発の要となるため，その技術開発に さらに磨きをかける必要があると考えている，鳥取とい う地の利を最大限に活かし, 高性能・低コスト・長寿命 のバランスのとれた LED 光源，LED 照明製品を鳥取の 地から発信していきたい.ベンチャー企業であるので, まずは，経営基盤の強化が喫緊の課題であることに変わ りはない.

お客様のニーズに合わせた照明設計をまずは進めてい く，光源，灯具の組み合わせをまずは提案し，一方で弊 社オリジナルの照明製品を開発・提案していきたいと考 えている，これを，実現させる技術として，LED光源 技術，電源回路技術があると考えている．当然，弊社単 独では限られたことしかできない。できるだけ多くの中 小・零細企業および地域と連携をし，できる業務の幅を 広げながら，商品開発力をつけていきたい，現在，商圈 は鳥取近郊に限られているが，紹介したような鳥取発の 事業のやり方を全国に通用するような方法に進化させて いきたいと考えている.

少し大風呂敷かもしれないが，LEDのベア・チップ の組み立てから, 照明器具の開発製造, そして, 照明設 計までを一貫して実行できる LED 照明製品の事業のあ り方を検討し，実現していきたい.

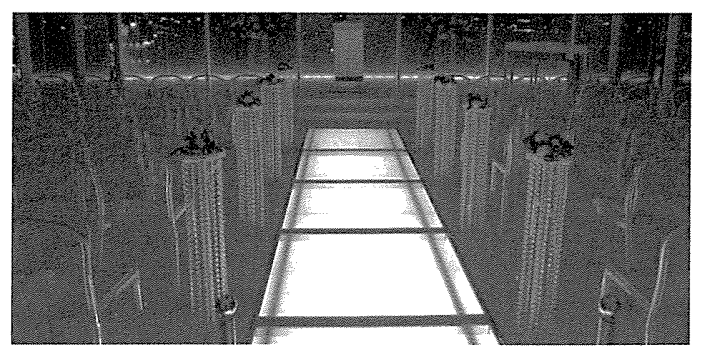

図 5 演出照明例

Fig.5 Example of LED lighting for the production.

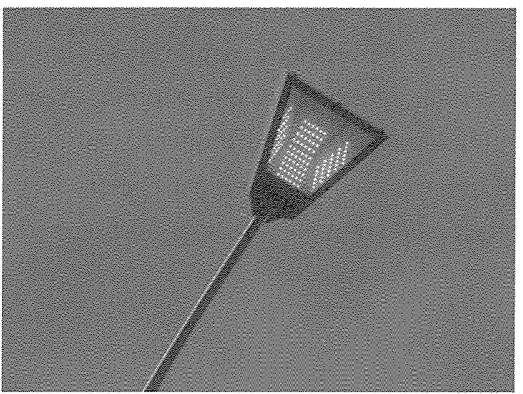

図6 LED 道路灯事例

Fig.6 Example of LED street lights.

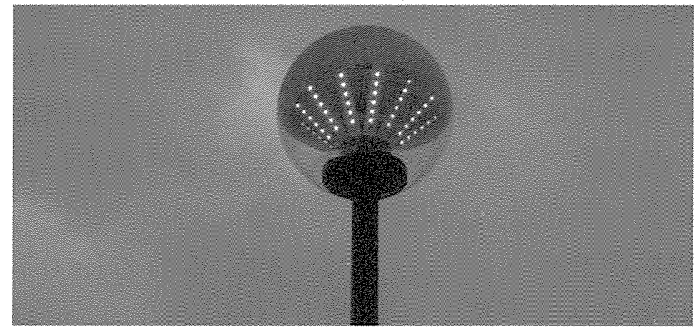

図 7 街路灯の LED 化事例

Fig.7 Example of modification of LED street lights.

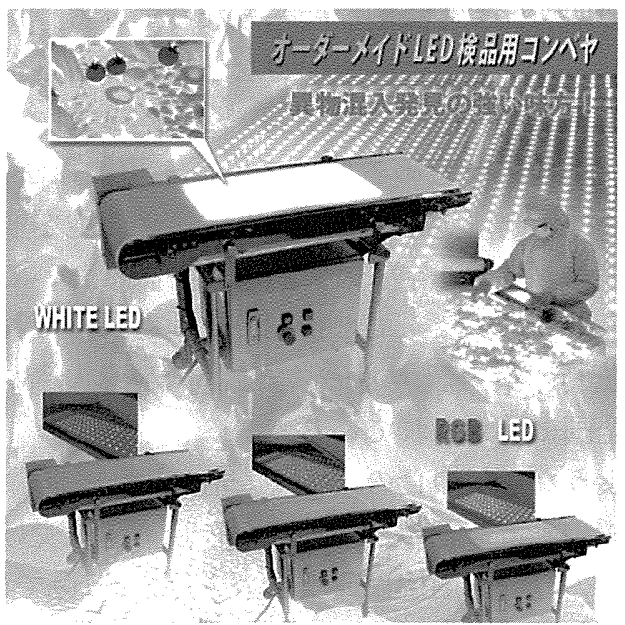

図 8 LED カラーコンベア例

Fig.8 Case of full color LED light source made of conveyor.

\section{連絡先}

T689-1112 鳥取県鳥取市若葉台南7-5-1

5-1, WakabadaiMinami7-chome, Tottori, Japan, 689-1112

E-mail : tanaka.akito@vierlight.co.jp 